\title{
Keputusan Konsumen Memilih Jasa Transportasi Go-Jek
}

\author{
Yuliana \\ Sekolah Tinggi Agama Islam Hubbulwathan Duri \\ yulianashime09@gmail.com
}

\begin{abstract}
Abstrak
Penelitian ini dilatarbelakangi, karena Fenomena yang terjadi sekarang ini bahwa masyarakat cenderung mengunakan jasa transportasi Go-Jek untuk kepentingan keseharian mulai dari mengantar ke pasar, kampus, dan memesan makanan. Mengunakan aplikasi jasa transportasi Go-Jek yaitu Go-Ride dan GoCar. Adapun rumusan masalah dalam penelitian ini adalah mengapa keputusan konsumen memilih jasa transportasi Go-Jek?. Adapun tujuan yang ingin dicapai dalam penelitian ini adalah untuk mengetahui alasan keputusan konsumen memilih jasa transportasi Go-Jek. Penelitian ini merupakan penelitian lapangan (field research) dengan menggunakan metode kualitatif, yang bertumpu pada pengumpulan data dengan observasi, wawancara, dan dokumentasi. Subjek atau sumber data primer adalah 50 orang yang dipilih dengan teknik Snowball Sampling adalah teknik pengambilan sampel sumber data yang awalnya jumlahnya sedikit lama-lama menjadi besar. Analisis penelitian menggunakan metode analisis deskriptif kualitatif. Setelah tahapan lapangan selesai, maka kesimpulan yang diperoleh kemudian dianalisis dalam konteks ekonomi syariah terhadap keputusan konsumen memilih jasa transportasi Go-Jek. Penulismenyimpulkan kehadiran jasa transportasi GoJek yaitu pada aplikasi Go-Ride dan Go-Car memberikan kepuasan (mashlahah) terdiri dari manfaat dan berkah dalam memenuhi kebutuhan manusia yang bertujuan memudahkan kehidupan dan menghilangkan kesempitan (hajjiyah) dan menghendaki kehidupan yang indah dan nyaman (tahsiniyah). Dalam perspektif Islam, kebutuhan ditentukan oleh mashlahah. Konsep kebutuhan dalam Islam tidak dapat dipisahkan dari perilaku konsumen dalam kerangka Maqasid Syariah. Di mana tujuan Syariah harus dapat menentukan tujuan perilaku kosumen dalam Islam. Pada sistem jasa transportasi Go-Jek memberikan kemudahan, tarif biaya yang terjangkau, waktu yang cepat dan tepat, kenyamanan fasilitas, serta keaman informasi pribadi pengguna.
\end{abstract}

Kata Kunci: Keputusan Konsumen, Transportasi dan Go-Jek.

\section{PENDAHULUAN}

Tujuan Ekonomi Islam adalah menciptakan manusia yang aman dan sejahtera. Al-Quran dan hadits menyebutkan sejumlah kehidupan yang baik dan dengan sengaja Allah menciptakannya untuk hamba-Nya. Salah satu tanda yang 
jelas tentang kenikmatan yaitu nikmat kendaraan, baik itu hewan ataupun mobil. Terdapat dalam surat an-Nahl: 8:

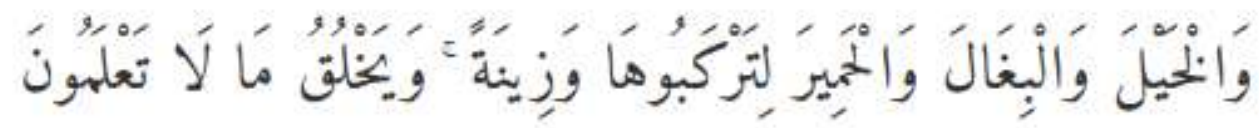

Artinya: Dan (Dia Telah menciptakan) kuda, bagal dan keledai, agar kamu menungganginya dan (menjadikannya) perhiasan. dan Allah menciptakan apa yang kamu tidak mengetahuinya.

Nabi juga menyebutkan bahwa di antara unsur kebahagian ialah kendaraan yang nyaman. Para fuqaha menyebutkan bahwa kuda termasuk kebutuhan asasi manusia. Jika dianalogikan, maka kuda pada zaman Nabi sama dengan mobil pada saat ini. Mobil, sarana yang mendekatkan jarak yang jauh itu sangat dibutuhkan dalam kehidupan seseorang sehingga ia sangat mengharapkannya. Mereka yang kurang mampu ingin memiliki sepeda motor. Kalau ia juga belum mampu memilikinya, negara dianjurkan untuk menyediakan angkutan umum (Yusuf Qardhawi, 1997: 61).

Demikian juga Islam mengatur segenap perilaku manusia dalam memenuhi kebutuhan hidupnya. Dalam masalah konsumsi, Islam mengatur bagaimana manusia bisa melakukan kegiatan-kegiatan konsumsi yang membawa manusia berguna bagi kemaslahatan hidupnya (Heri Sudarsono, 2004: 167). Perilaku konsumen berusaha memahami bagaimana konsumen mencari, membeli, menggunakan, mengevaluasi, dan menghabiskan produk dan jasa. Setiap konsumen melakukan berbagai macam keputusan tentang pencarian, pembelian, penggunaan beragam produk, dan merek pada setiap periode tertentu. Berbagai macam keputusan mengenai aktivitas kehidupan seringkali harus dilakukan oleh setiap konsumen pada setiap hari.

Keputusan konsumen merupakan tahapan proses akhir dari serangkaian tahapan proses yang terjadi pada perilaku konsumen. Keputusan konsumen membeli, merangkum tiga tahapan proses yakni proses masuknya informasi, proses pertimbangan konsumen dalam membeli, dan diakhiri dengan proses pengambilan keputusan konsumen. Dalam hal ini keputusan seorang konsumen tidak selalu dalam bentuk keputusan untuk membeli, melainkan juga berupa keputusan untuk 
menunda membeli atau keputusan untuk tidak membeli sama sekali (Mulyadi Nitisusanto, 2012: 195).

Menurut Jusmaliani, (2008: 199) Pada perkembangan dalam berbagai teknologi, transportasi dan telekomunikasi membuat dunia berkembang. Teknologi online, transaksi bisa dilakukan di mana pun dan kapan pun. Begitu banyak kemudahan yang bisa didapat. Seiring dengan kemajuan teknologi informasi dan komunikasi yang telah mengubah perekonomian dunia, terutama praktik bisnis modern sehingga transaksi bisnis pun dengan pesat berkembang. Upaya pemasan dapat sekaligus dilakukan melalui fasilitas internet. Penggunaan fasilitas memungkinkan aktivitas bisnis dilakukan di mana, dan kapan pun tanpa mempertemukan pihak yang bertransaksi secara fisik.

Kecanggihan teknologi ICT (Information Commnuication Technology) dewasa ini telah banyak memengaruhi dan bahkan mengubah berbagai aspek kehidupan masyarakat. Kemajuan teknologi informasi yang diwujudkan dalam bentuk media komunikasi dan informasi ini telah membuat dunia makin kecil. Besarnya pengaruh perkembangan teknologi informasi dan komunikasi pada kehidupan masyarakat saat ini. Perkembangan ICT telah mengubah gaya hidup masyarakat modern. Perubahan gaya hidup ini dapat dilihat pada salah satu aspek kehidupan masyarakat, yaitu cara masyarakat berkomunikasi dengan media online.

Cara atau alat yang digunakan untuk memenuhi berbagai kebutuhan manusia, berubah sesuai dengan perkembangan zaman yaitu dengan ditemukannya teknologi komunikasi dan informasi (Information Commnuication Technology, ICT) yang melahirkan media terhubung atau internet dengan menyajikan alternatif baru cara berkomunikasi. Di era informasi seperti saat ini, kehidupan masyarakat sulit dipisahkan dari media online.

Di sisi lain, perkembangan di bidang teknologi komunikasi membawa dampak yang cukup besar pada berbagai bidang perekonomian. Kemajuan teknologi sekarang ini, terutama kemajuan teknologi komunikasi yang cukup pesat memberikan perubahan sosial masyarakat. Banyak bisnis mulai bermunculan dengan memanfaatkan perkembangan teknologi komuniksi tersebut, salah satunya adalah kemunculan bisnis penyedia layanan jasa transportasi Go-Jek di Kota 
Padang, kantor yang beralamat di Jalan Imam Bonjol No 21 A, Belakang Pondok, Padang Selatan, Kota Padang.

Perusahaan Go-Jek merupakan perusahaan yang didirikan oleh anak bangsa yang bernama Nadiem Makarim bersama temannya Michaelangelo Moran pada bulan Maret 2011, yang bertujuan untuk mengurangi pengganguran di Indonesia dan menjadi solusi kemacetan. Cara kerja Go-Jek yaitu menggunakan aplikasi yang terhubung dengan internet. Para pelanggan tidak perlu menunggu dipinggir jalan atau mendatanggi kepangkalan ojek. Pemesanan melalui aplikasi Go-Jek sesuai kebutuhan. Go-Jek siap untuk melayani pelanggan yang berada di mana saja. Jasa transportasi Go-Jek meliputi:

a. Go-Ride memberikan jasa transportasi kepada konsumen untuk mengantarkan pengguna berpergian ke tempat yang diinginkan menggunakan sepeda motor.

b. Go-Car memberikan jasa transportasi ke konsumen utuk mengantarkan pengguna berpergian dengan menggunkan mobil pribadi.

c. Go-Bluebird pengantaran konsumen ke tempat yang diinginkan dengan menggunakan taxi.

d. Go-Food melayani pesan antar makanan ke alamat yang diinginkan. Konsumen dapat memilih makanan dan restoran yang diinginkan melalui aplikasi yang tersedia.

e. Go-Send melayani pengiriman barang dengan menggunakan sepeda motor yang dapat dipesan secara online.

f. Go-Pulsa melayani pengisian pulsa dengan pengemudi datang ke lokasi pemesan kemudian melakukan transaksi pengisian.

g. Go-Bills melayani jasa pengiriman tagihan kepada konsumen pemesan ke toko untuk pembayaran tagihan belanja.

h. Go-Shop melayani jasa pembelian ke toko untuk keperluan keseharian seperti toko pakain dan yang lainnya.

i. Go-Mart memberikan jasa untuk berbelanja kebutuhan sehari-hari pengguna. Dapat melayani pembelajaan di supermarket, dan toko pembelanjaan lainnya. Pengemudi Go-Jek akan membeli barang pesanan dan mengantarkannya ke alamat yang dituju. 
j. Go-Tix melayani jasa pemesanan tiket yang di pesan konsumen untuk menonton suatu acara sepeti bioskop, pesawat, dan kereta api.

k. Go-Box melayani mengangkut barang dalam jumlah banyak, denagn mengunakan mobil bak terbuka ataupun tertutup. Dapat dimanfaatkan oleh konsumen untuk pindah rumah, pindah kantor, atau lainnya.

1. Go-Massage melayani jasa pijat yang dipesan melalui aplikasi Go-Jek. Dapat dengan mendatangi langsung ke lokasi keberaan pemesan.

m. Go-Clean melayani jasa membersihkan rumah. Menyediakan satu orang asisten rumah tangga untuk membersihkan rumah.

n. Go-Glam melayani jasa kecantikan kepada konsumen. Pelayanan dapat di lakukan di rumah.

o. Go-Auto melayani jasa otomotif datang langsung untuk memperbaiki seperti mobil yang sedang rusak di lokasi pemesan.

p. Go-Med melayani jasa kunci pengguna yang berada di rumah dan tempat lainnya.

q. Go-Busway melayani pengantaran pengguna ke halte busway tertentu. Menyediakan informasi untuk melacak keberadaan dan kehadiran busway di setiap halte.

Pelanggan dapat menentukan tempat penjemputan dan tempat pengantaran, kemudian menampilkan tarif bayaran. Dengan ditampilkannya tarif langsung saat memesan, maka pelanggan akan lebih mudah dan tahu beberapa biaya yang harus disiapkan. Jasa transportasi Go-Jek telah dipercaya beragam pelanggan dalam membantu aktifitas. Sebagai perusahaan yang sedang berkembang pesat. Kepuasan pelanggan terhadap layanan dan hasil kinerja akan sangat mempengaruhi perusahaan, sehingga hal ini menjadi perhatian penting bagi perusahaan yang sedang berkembang pesat seperti jasa transportasi Go-Jek.

Berdasarkan rumusan masalah yang telah dipaparkan di atas, maka tujuan penelian ini adalah untuk mengetahui keputusan konsumen memilihjasatransportasiGo-Jek.Kegunaan Penelitian ini diharapkan dapat menambah wawasan tentang analisisterhadap keputusan konsumen memilih jasa transportasi Go-Jek di Kota Padang, bagi kalangan akademis menambah wawasan 
keilmuwan bagi pembaca khususnya penyusunan yang akan membahas tentang analisis terhadap keputusan konsumen memilih jasa trannsportasi Go-Jek di Kota Padang, bagi masyarakat hasil penelitian ini dapat menjadi bahan pertimbangan untuk memilih dan memutuskan jasatransportasi Go-Jek ataupun Ojek Pangkalan, Angkot, Trans Padang, Bus Kota dan lainya.

\section{KERANGKA TEORI}

\section{Norma dan Etika Konsumen dalam Islam}

Setiap orang mukmin berusaha mencari kenikmatan dengan cara memenuhi perintah-Nya dan memuaskan dirinya sendiri dengan barang-barang dan anugerah yang di ciptakan Allah untuk umat manusia demi kemaslahatan. Konsumsi berlebih-lebihan, yang merupakan ciri khas masyarakat yang tidak mengenal Tuhan, dan disebut dengan israf (pemborosan) atau tabzir menghambur-hamburkan harta tanpa guna.

Tabzir berarti menggunakan harta dengan cara yang salah, yakni menuju tujuan yang terlarang, hal-hal yang melanggar hukum atau dengan cara yang tanpa aturan. Pemborosan berarti penggunaan harta secara berlebihan untuk halhal yang melanggar hukum dalam hal seperti makanan, pakaian, tempat tinggal. Ajaran Islam menganjurkan pola konsumsi dan penggunaan harta secara wajar dan berimbang, yakni pola yang terletak di antara kekikiran dan pemborosan. Konsumsi di atas dan melampaui tingkat moderat dianggap israf dan tidak disenangi Islam.

Salah satu ciri penting dalam Islam bahwa ia tidak hanya mengubah nilai-nilai dan kebiasaan masyarakat tetapi juga menyajikan kerangka legislatif yang perlu untuk mendukung dan memperkuat tujuan-tujuan ini dan menghindari penyalahgunaannya. Ciri khas Islam ini juga memiliki daya aplikatifnya terhadap orang yang terlibat dalam pemborosan atau tabzir.Etika Islam dalam hal konsumsi sebagai berikut (Rianto dan Amalia, 2010: 86);

a. Tauhid

Yaitu dalam persepektif Islam, kegiatan konsumsi dilakukan dalam rangka beribadah kepada Allah SWT, sehingga senantiasa berada dalam 
hukum Allah (Syariah). Karena itu, orang mungkin berusaha mencari kenikmatan dengan menaati perinyah-Nya dan memuaskan dirinya sendiri dengan barang-barang dan anugerah yang diciptakan Allah untuk umat manusia. sebagaimana QS adz-Dzaariyat (51):56

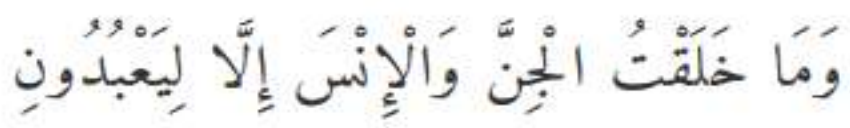

Artinya: Dan Aku tidak menciptakan jin dan manusia melainkan supaya mereka mengabdi kepada-Ku.

b. Adil (Rianto dan Amalia, 2010: 87)

Yaitu Islam memperbolehkan manusia untuk menikmati berbagai karunia kehidupan dunia yang disediakan Allah SWT. Dalam QS al- A'raaf (7):32

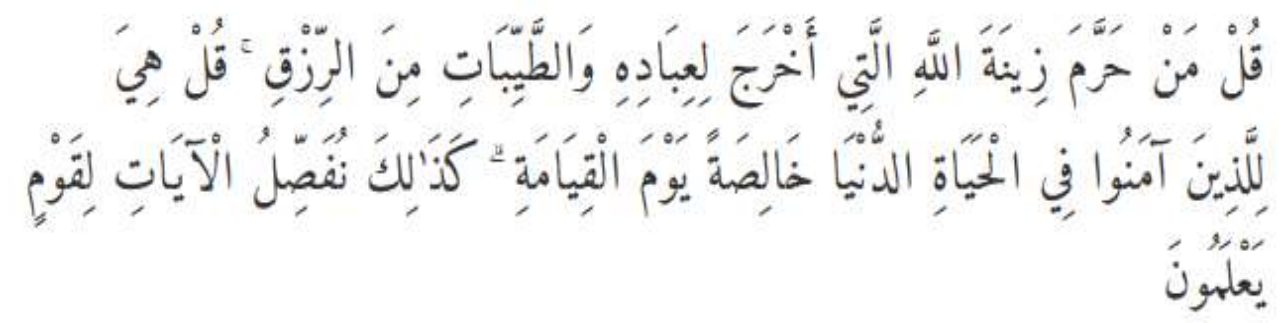

Artinya: Katakanlah: "Siapakah yang mengharamkan perhiasan dari Allah yang Telah dikeluarkan-Nya untuk hamba-hamba-Nya dan (siapa pulakah yang mengharamkan) rezki yang baik?" Katakanlah: "Semuanya itu (disediakan) bagi orang-orang yang beriman dalam kehidupan dunia, khusus (untuk merekasaja) di hari kiamat." Demikianlah kami menjelaskan ayat-ayat itu bagi orang-orang yang Mengetahui.

Pemanfaatan atas karunia Allah tersebut harus dilakukan secara adil sesuai dengan Syariah, sehingga di samping mendapatkan keuntungaan materiil, ia juga sekaligus merasakan kepuasan spiritual. Al-Quran secara tegas menekankan norma perilaku ini baik untuk hal-hal yang bersifat materiil maupun spiritual untuk menjamin adanya kehidupan yang berimbang antara kehidupan dunia dan akhirat. Oleh karenanya, dalam Islam konsumsi tidak hanya barang-barang yang bersifat duniawi semata, namun juga untuk kepentingan di jalan Allah (fisabilillah). 
c. Kehendak Bebas (Rianto dan Amalia, 2010: 90)

Yaitu alam semesta merupakan milik Allah, yang memiliki kemahakuasaan (kedaulatan) sepenuhnya dan kesempurnaan atas makhlukmakhluk-Nya. Manusia diberi kekuasaan untuk mengambil keuntungan dan manfaat sebanyak-banyaknya sesuai dengan kemampuannya atas barangbarang ciptaan Allah,

d. Amanah (Rianto dan Amalia, 2010: 90)

Yaitu manusia merupakan khalifah atau pengemban amanat Allah SWT. Manusia diberi kekuasaan untuk melaksanakan tugas kekhalifahan ini dan untuk mengambil keuntungan dan manfaat sebanyak-banyaknya atas ciptaan Allah. Dalam hal melakukan konsumsi, manusia dapat berkehendak bebas tetapi akan mempertanggungjawabkan atas kebebasan tersebut baik terhadap keseimbangan alam, masyarakat, diri sendiri maupun di akhirat kelak. Pertanggungjawaban sebagai seorang muslim bukan hanya kepada Allah SWT namun juga kepada lingkungan,

e. Halal

Dalam kerangka acuan Islam, barang-barang yang dapat dikonsumsi hanyalah barang-barang yang menunjukkan nilai-nilai kebaikan, kesucian, keindahan, serta akan menimbulkan kemaslahatan untuk umat baik secara meteriil maupun spritual,

f. Sederhana

Yaitu Islam sangat melarang perbuatan yanng melampaui batas (israf), termasuk pemborosan dan berlebih-lebihan (bermewah-mewah), yang itu membuang-buang harta dan mengahambur-hamburkannya tanpa faedah serta manfaat dan hanya memperturutkan nafsu semata. Allah akan sangat mengecam setiap perbuatan yang melampaui batas.QS al-A'raaf (7):31

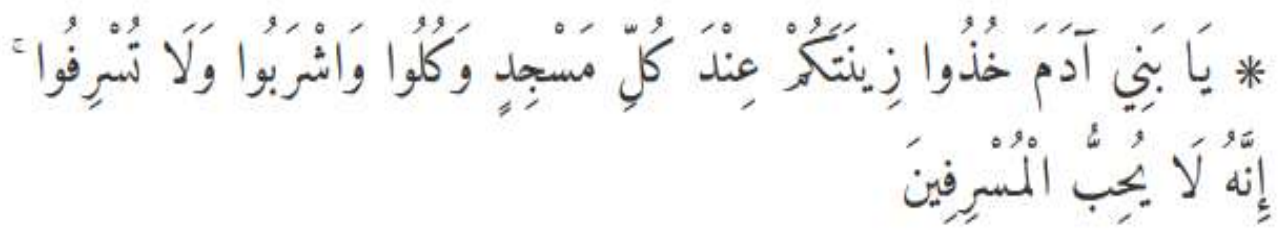


Artinya: Hai anak Adam, pakailah pakaianmu yang indah di setiap (memasuki) mesjid, makan dan minumlah, dan janganlah berlebih-lebihan. Sesungguhnya Allah tidak menyukai orang-orang yang berlebih-lebihan.

Berdasarkan penjelasan di atas etika Islam dalam hal konsumsi dapat dipahami bahwa sebagai manusia harus sesuai dengan tauhid, adil, kehendak bebas, amanah, halal, dan sederhana dalam mengunakan produk barang atau jasa.

\section{Maqasid Syariah dalam Ekonomi Islam}

Dalam membandingkan konsep kepuasan dengan pemenuhan kebutuhan (yang terkandung di dalamnya mashlahah perlu membandingkan tinngkatan-tingkatan tujuan hukum syara' yakni antara dlaruriyah, hajjiyah dan tahsiniyah yaitu (Edwin Naution, 2007: 64) ; a) Dlaruriyah: tujuan yang harus ada dan mendasar bagi penciptaaan kesejahteraan di dunia dan akhirat yaitu mencakup terpeliharanya lima elemen dasar kehidupan yakni agama, jiwa, akal, keturunan dan harta. Jika tujuan ini diabaikan maka tidak akan ada kedamaian yang timbul adalah kerusakan di dunia dankerugian yang nyata di akhirat, b) Hajjiyah: syariah bertujuan memudahkan kehidupan dan menghilangkan kesempitan. Hukum syara' dalam kategori ini tidak dimaksudkan untuk memelihara lima hal pokok tadi melainkan menghilangkan dan berhati-hati terhadap lima hal pokok tersebut, c) Tahsiniyah: syariah menghendaki kehidupan yang indah dan nyaman di dalamnya. Terdapat beberapa provisi dalam syariah yang dimaksudkan untuk mencapai pemanfaatan yang lebih baik, keindahan dan simplikasi dari dlaruriyah dan hajjiyah.

Jika maqasid al-syariah menghendaki tercapainya suatu mashlahah, maka secara logis konsep ini juga menghindari pada apa yang sering kita sebut sebagi mafsadah (kerusakan). Mafsadah merupakan kebaikan dari mashlahah. Jika mashlahah ingin dicapai oleh maqasid al-syariah, maka mafsadah ingin dan harus dihindarinnya. Hakikat perintah dan larangan syara' pada dasarnya untuk mewujudkan tujuan syariah yang dikembalikan pada suatu kaidah jalb 
al-masahlih wa dar'u al-mafasid (menarik kemaslahatan dan menolak kerusakan) (Edwin Nasution: 2007: 47).

\section{Mashlahah dalam Konsumsi}

Dalam ekonomi Islam, kepuasan dikenal dengan mashlahah dengan pengertian terpenuhi kebutuhan baik bersifat fisik maupun spritual. Islam sangat mementingkan keseimbangan kebutuhan fisik dan nonfisik yang didasarkan atas nilai-nilai Syariah. Kepuasan seorang muslim tidak didasarkan banyak sedikitnya barang yang dikonsumsi, tetapi didasarkan atas berapa besar nilai ibadah yang didapatkan dari yang dikonsumsimnya (Rozalinda, 2014: 97).

Sebagaimana bahwa kandungan mashlahah terdiri dari manfaat dan berkah. Demikian pula dalam hal perilaku konsumsi, seorang konsumen akan mempertimbangkan manfaat dan berkah yang dihasilkan dari kegiatan konsumsinya. Konsumen merasakan adanya manfaat suatu kegiatan konsumsi ketika ia mendapatkan pemenuhan kebutuhan fisik atau psikis atau meteril.

\section{Proses Masuknya Informasi}

Pada proses masuknya informasi, konsumen dipengaruhi oleh faktor eksternal yang di dalamnya terdapat dua sub-faktor, meliputi sub-faktor upaya para pemasar perusahaan dan sub-faktor sosial-budaya (Kotler, 2006: 196):

a. Upaya Para Pasar

Dilihat dari sudut pandang perusahaan, upaya para pemasaran ini merupakan kegiatan yang dirancang melalui strategi pemasaran masingmasing perusahaan. Komunikasi pemasaran yang dijalankan oleh setiap perusahaan berisi pesan-pesan pemasaran yang dalam penyampaiannya menggunakan berbagai instrumen pemasaran atau bauran pemasaran (Marketing Mix). Bauran-bauran pemasaran tersebut mempengaruhi konsumen, penjelasannya sebagai berikut (Kotler, 2006: 97);a) Produk (Product), b) Harga (Price), c) Saluran Distribusi (Channel of Distribution), d) Promosi (Promotion), e) Proses (Process), f) Pendukung Fisik (Physical Evidents), dan g) Orang (Peoples). 
b. Lingkungan Sosial-Budaya

Pengaruh lingkungan sosial budaya (Socio-Cultural Input), unsurunsurnya bersumber dari lingkungan sosial-budaya seperti, keluarga, sumber-sumber informasi tidak formal, sumberi informasi yang berasal dari informasi non komersial lainnya, kelas sosial, dan pengaruh budaya dan sub-budaya lainnya. Secara sederhana unsur-unsur lingkungan sosial budaya dijelaskan seperti berikut ( Kotler, 2006; 207): a) Budaya (Culture), budaya adalah karakter dari seluruh masyarakat yang didalamnya meliputi faktor-faktor bahasa, pengetahuan, hukum, agama, kebiasaan-kebiasaan makan, musik, seni, teknologi, pola kerja, dan lain-lainnya, b) Demografi (Demography), merupakan ilmu yang mempelajari tentang kependudukan dalam hal ukuran, struktur dan penyebaran. Ukuran berati jumlah orang, struktur menggambarkan usia, pendapatan, pendidikan dan pekerjaan, distribusi menggambarkan penyebaran lokasi, c) Kelas Sosial (Social Class). Kelas sosial didefinisikan dengan satu rangkaian tingkatan posisi sosial ekonomi, dimana tiap anggota dari tingkatan-tingkatan strata menempati posisinya atau sejumlah kelompok yang membagi-bagi kelompoknya dalam strata tingkatan sosial ekonomi, d) Referensi Kelompok (Referrence Group), referensi kelompok adalah seseorang atau kelompok orang yang dijadikan acuan oleh seorang dalam membentuk pandangan tentang nilai tertentu, sikap atau pedoman berperilaku yang memiliki ciri-ciri khusus. Pendapat lain menyatakan bahwa referensi kelompok adalah perorangan atau kelompok nyata atau maya yang membayangkan mempunyai kesamaan penilaian aspirasi atau perilaku, e) Keluarga (Family, keluarga adalah keluarga yang lengkap, terdiri dari tiga generasi yang hidup bersama dan yang sering terjadi tidak hanya kakek dan nenek, akan tetapi juga paman, bibi, keponakan, dan kerabat lainnya. Unit keluarga terdiri dari dua atau lebih orang yang saling memiliki keterkaitan yang tinggal dan makan dalam tempat tinggal pribadi. 


\section{Proses Keputusan Konsumen}

Selanjutnya, keputusan konsumen bisa berupa beberapa kemungkinan, yakni membeli, menunda atau tidak membeli. Untuk menunda membeli secara langsung dapat dikategorikan sebagai tidak atau belum membeli. Menunda membeli disebabkan oleh beberapa pertimbangan, antara lain belum merasa yakin terhadap barang yang akan dibeli atau ada faktor-faktor lainnya. Setelah keputusan diambil maka dengan sendirinya konsumen bisa memanfaatkan barang yang telah dibeli untuk berbagai tujuan. Salah satu tujuan adalah untuk memenuhi kebutuhan dan atau menyelesaikan masalah yang dihadapi. Bila demikian keadaannya, maka konsumen dapat merasakan sendiri apakah barang yang telah dibeli tersebut mampu memenuhi kebutuhannya, dalam arti mampu memberikan solusi yang diharapkan. Apabila barang yang telah dibeli mampu memenuhi kebutuhan yang diharapkan, maka konsumen tersebut merasakan kepuasan. Sebaliknya apabila barang yang telah dibeli tidak mampu memenuhi kebutuhannya atau bahkan membuat kesulitan, maka konsumen menjadi tidak puas ( Kotler: 2006: 215).

Dalam penelitian sebelumnya yang dilakukan oleh Fania Darma Amajida, Departemen Sosiologi Universitas Indonesia, infornasi kajian ilmu komunikasi volume 46 nomor 1 Juni 2016, judul, Kreativitas Digital dalam Masyarakat Risiko Perkotaan: Studi tentang Ojek Online “Go-Jek” di Jakarta. Moda transportasi berbasis aplikasi muncul sebagai wujud dari perkembangan teknologi dan reaksi atas kelemahan penyedia jasa transportasi publik. Studi ini memperlihatkan bahwa aplikasi yang digunakan ojek online "Go-Jek" mampu meminimalisir risiko yang terjadi di Jakarta dalam hal waktu, kemudahan, biaya, dan keamanan. Pengumpulan data dalam studi ini menggunakan metode kualitatif.Berdasarkan kajian relevan yang telah dijelaskan diatas bahwa pada penelitian penulis mempunyai perbedaan. Penelitian penulis dimana transportasi Go-Jek pada aplikasi Go-Ride dan Go-Car memberikan kemudahan, tarif biaya yang terjangkau, waktu yang cepat dan tepat, kenyamanan fasilitas, dan keaman informasi pribadi pengguna. Kemudian ditinjau dari ekonomi syariah kehadiran transportasi Go-Jek memberikan mashlahah kepada masyarakat di kota Padang. 


\section{METODOLOGI}

Jenis penelitian ini adalah penelitian lapangan (field research), dengan metode ini penulis melakukan penelitian guna mengumpulkan data yang bersumber dari subjek yang diteliti. Penelitian ini pada hakekatnya merupakan metode yang menentukan secara khusus dari realita yang terjadi di tengah masyarakat (Kartini Kartono, 1990: 3). Penelitian ini digunakan untuk memahami makna di balik data untuk menemukan kebenaran (Moh. Nazir, 2005: 54). Penelitian kualitatif dengan menggunakan metode deskriptif. Penelitian ini bertujuan untuk membuat deskripsi, gambaran, dan lukisan tentang Analisis terhadap Keputusan Konsumen Memilih Jasa Transportasi Go-Jek di Kota Padang.

Situasi sosial yang menjadi fenomena transportasi Go-Jek di kota Padang, bahwa konsumen cenderung mengunakan aplikasi Go-Jek tersebut untuk melakukan berbagai macam kegiatan. Seperti: kegiatan ke universitas, pasar, tempat kerja dan pemesanan makanan. Para penguna transportasi Go-Jek yang terjadi situasi sosial bahwa pengemudi jasa transportasi Go-Jek ada di mana-mana pada daerah di kota Padang. Oleh sebab itu untuk memperoleh data tersebut dari narasumber, penulis menariknya dengan metode pengambilan responden yang digunakan dalam penelitian ini adalah dengan pendekatan Nonprobability Sampling, setiap unsur dalam populasi tidak memiliki kesempatan atau peluang yang sama untuk dipilih sebagai sampel, bahkan probalitas anggota populasi tertentu untuk dipilih tidak diketahui.

Pengambilan sampel mengunakan Snowball Sampling yaitu teknik penentuan sampel berdasarkan kebetulan, yaitu teknik pengambilan sampel sumber data, yang pada awalnya jumlahnya sedikit, lama-lama menjadi besar. Hal ini dilakukan karena dari jumlah sumber data yang sedikit itu tersebut belum mampu memberikan data yang memuaskan, maka mencari orang lain lagi yang dapat digunakan sebagai sumber data. Dengan demikian jumlah sampel sumber data akan semakin besar, seperti bola salju yang menggelinding, lama-lama menjadi besar.

Penulis melakukan wawancara kepada 50 orang yang mengunakan transportasi Go-Jek. Pada aplikasi Go-Ride dan Go-Car, jenis pekerjaan yang 
menggunakan jasa transportasi Go-Jek adalah mahasiswa sebanyak 30 orang. Pegawai sebanyak 5 orang. Siswa-Siswi sebanyak 5 orang. Ibu rumah tangga sebanyak 5 orang. Buruh adalah sebanyak 5 orang.

\section{PEMBAHASAN}

\section{Kemudahan}

Dalam bisnis jasa, proses merupakan bagian dari produk dan kualitas. Perusahaan penjual produk jasa perlu menjalankan berbagai kebijakan yang bertujuan untuk mempermudah seluruh proses yang merupakan bagian dari produk dan kualitas. Setiap perusahaan akan melakukan berbagai usaha dan upaya perbaikan secara terus menerus agar konsumen melakukan kegiatan membeli. Konsumen akan terus termotivasi membeli disebabkan proses yang mudah, dan menyenangkan (Mulyadi Nitisusanto, 2012: 204).Pada perkembangan dalam berbagai teknologi, transportasi dan telekomunikasi membuat dunia berkembang. Teknologi online, transaksi bisa dilakukan di mana pun dan kapan pun. Begitu banyak kemudahan yang bisa didapat. Upaya pemasan dapat sekaligus dilakukan melalui fasilitas internet. Penggunaan fasilitas memungkinkan aktivitas bisnis dilakukan di mana, dan kapan pun tanpa mempertemukan pihak yang bertransaksi secara fisik (Jusmaliani, 2008: 199).

Kecanggihan teknologi ICT (Information Commnuication Technology) dewasa ini telah banyak memengaruhi dan bahkan mengubah berbagai aspek kehidupan masyarakat. Besarnya pengaruh perkembangan teknologi informasi dan komunikasi pada kehidupan masyarakat saat ini. Perkembangan ICT telah mengubah gaya hidup masyarakat modern. Perubahan gaya hidup ini dapat dilihat pada salah satu aspek kehidupan masyarakat, yaitu cara masyarakat berkomunikasi dengan media online.

Media online yang sudah menjadi bagian dari kehidupan sehari-hari saat ini. Berkaitan dengan cara atau usaha manusia dalam memenuhi keperluan hidupnya kebutuhan dan keinginan melalui media.Seperti jasa transportasi Go-Jek yang berbagai macam aplikasi, misalnya Go-Ride dan Go-Car memberikan kemudahan. Dalam memenuhi kebutuhan dan keinginan dengan mengunakan jasa Go-Jek. 
Islam mengatur segenap perilaku manusia dalam memenuhi kebutuhan hidupnya. Dalam masalah konsumsi, Islam mengatur bagaimana manusia bisa melakukan kegiatan-kegiatan konsumsi yang membawa manusia berguna bagi kemaslahatan hidupnya (Heri Sudarsono, 2004: 167).

Sebagaimana bahwa kandungan mashlahah terdiri dari manfaat dan berkah. Demikian pula dalam hal perilaku konsumsi, seorang konsumen akan mempertimbangkan manfaat dan berkah yang dihasilkan dari kegiatan konsumsinya. Konsumen merasakan adanya manfaat suatu kegiatan konsumsi ketika ia mendapatkan pemenuhan kebutuhan fisik atau psikis atau meteril.

Berdasarkan hasil wawancara penulis kepada Fla Mulyani menyatakan mengunakan aplikasi Go-Car untuk mengantarkan ke tempat kerja bersama teman satu kantor. Terkadang mengunakan aplikasi Go-Ride untuk pesan antar makanan. Sebelumnya mengunakan ojek pangkalan ke luar gang rumah. Kemudian mengunakan angkot ke lokasi kerja.

Sherly Dwiagustin mengatakan sebelum kehadiran jasa transportasi Go-Jek, melakukan pengiriman barang untuk orang tua langsung ke loket travel. Pergi ke tempat kerja mengunakan ojek pangkalan serta membeli makanan di sekitar lokasi kerja. Tetapi setelah jasa transportasi Go-Jek ada memberi kemudahan. Pada jasa transportasi Go-Ride yang menyediakan jasa pesan makanan. Setiap hari mengunakan jasa tersebut untuk membeli makanan yang sesuai selera. Dimana telah banyak kedai makanan yang bergabung di jasa transportasi Go-Jek.

Kemudian Sherly Dwiagustin mengirim barang untuk orang tua di kampung melalui jasa Go-Ride ke tempat travel tanpa menunggu pihak travel menjemput barang yang akan dikirim. Pengiriman tersebut dilakukan satu kali sebulan. Serta mengunakan setiap hari setelah ada jasa transportasi Go-Ride untuk pergi kerja jadwal siang maupun malam.

Mulia Aswa Dewi Putri mengatakan mengunakan jasa transportasi Go-Jek pada aplikasi co-car untuk mengantarkan ke tempat kerja. Sebelumnya menggunakan jasa transportasi umum yang sering kali angkot yang di tumpangi berhenti untuk mencari penumpang lain dalam waktu yang cukup lama. Hal ini membuang waktu dan sering kali menyebabkan terlambat ke tempat kerja. 
Nini Paramida mengatakan karena kehadiran jasa Go-Jek sangat di butuhkan pada saat sekarang ini. Untuk mengantarkan kegiatan rutinitas kuliah setiap harinya. Sebelumnya pergi ke kampus mengunakan angkot yang menghabiskan waktu yang lama di angkot sampai ketujuan. Dengan adanya jasa transportasi Go-Ride, memberikan kemudahan sehingga menghemat dari segi waktu dan tenaga. Menggunakan jasa Go-Ride mengantarkan ke lokasi tujuan dengan tempat waktu.

Elva Yusia Khairani mengatakan di mana pada keadaan yang sangat mendesak pada jadwal perkuliahan di siang hari. Sehingga dengan kehadiran jasa transportasi Go-Jek memberikan kemudahan di kalangan Mahasiswa. Sebelumnya mengunakan jasa angkot, kemudian setelah ada jasa transportasi Go-Jek, menggunakan jasa Go-Ride untuk ke kampus di mana jika terjadi macet di jalan raya, pengemudi Go-Ride dengan pengalaman membawa penumpang ke gang melewati kemacetan.

Dwi Yulinda mengatakan di mana Kampus yang jauh dari jalan raya, sehingga pengemudi Go-Jek mengantarkannya sampai lokasi tujuan. Di bandingkan jika mengunakan angkot hanya sampai di depan gerbang di antar kemudian jalan kaki hingga ke fakultas. Sebelumnya mengunakan angkot, tetapi harus jalan kaki dari tempat kost sekarang tidak lagi dengan adanya jasa transportasi Go-Jek. Pengemudi langsung menjemput ke lokasi dengan arahan yang beritahukan oleh pengguna jasa transportasi Go-Jek.

Andika mengatakan mengunakan jasa Go-Ride untuk mengatarkan pulang pergi ke sekolah serta ketempat bimbel. Sebelum adanya jasa transportasi Go-Jek, andika di antarkan oleh orang tua ke sekolah, sekarang setelah ada jasa Go-Ride andika mengunakan setiap hari ke sekolah. Dengan adanya jasa transportasi Go-Jek memberikan kemudahan di orang tua andika yang memiliki toko. Waktu yang digunakan untuk mengantarkan andika, digunakan untuk berjualan di toko.

Kemudian cara pemesanan transportasi jasa Go-Jek dilakukan melalui aplikasi yang tersedia di samrtphone. Dengan mengunakan smartphone konsumen tidak perlu lagi mencari transportasi di pinggir jalan ataupun pangkalan. konsumen kini dapat menunggu transportasi di lokasi mereka berada karena Go-Jek yang akan 
menghampiri pengguna. Perangkat smartphone yang digunakan memudahkan konsumen karena dinilai lebih fleksibel karena dapat dengan mudah dibawa kemana-mana.

Jasa transportasi Go-Jek merupakan sarana yang sangat dibutuhkan pada zaman sekarang karena dengan adanya transportasi dapat memilih jalur darat untuk memenuhi kebutuhannya. Ketergantungan masyarakat terhadap transportasi sangat tinggi, dengan alasan untuk mempersingkat waktu perjalanan. Salah satu tanda yang jelas tentang kenikmatan yaitu nikmat kendaraan, baik itu hewan ataupun mobil. Sebagaimana terdapat dalam surah an-Nahl (16): 8.

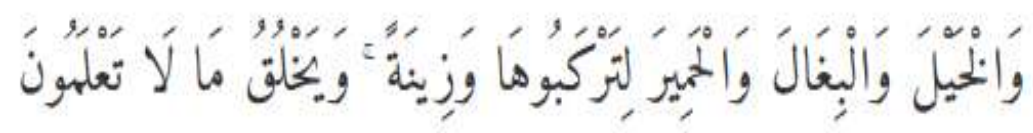

Artinya: Dan (Dia Telah menciptakan) kuda, bagal dan keledai, agar kamu menungganginya dan (menjadikannya) perhiasan. dan Allah menciptakan apa yang kamu tidak mengetahuinya.

Nabi juga menyebutkan bahwa di antara unsur kebahagian ialah kendaraan yang nyaman. Para fuqaha menyebutkan bahwa kuda termasuk kebutuhan asasi manusia. Jika dianalogikan, maka kuda pada zaman nabi sama dengan mobil pada saat ini. Mobil, sarana yang mendekatkan jarak yang jauh itu sangat dibutuhkan dalam kehidupan seseorang sehingga ia sangat mengharapkannya. Mereka yang kurang mampu ingin memiliki sepeda motor. Kalau ia juga belum mampu memilikinya, negara dianjurkan untuk menyediakan angkutan umum (Yusuf Qardhawi, 1997: 61).

Berdasarkan ayat di atas, bahwa jasa transportasi merupakan kebutuhan dasar pada zaman sekarang ini. Dengan adanya jasa transportasi yang berbasis online seperti jasa transportasi Go-Ride dan Go-Car memberikan kemudahan bagi seluruh masyarakat Kota Padang.

\section{Biaya}

Produk memberikan sejumlah nilai bagi konsumen. Mampu memberikan nilai dalam hal kemudahan bagi penggunanya. Produk jasa merupakan secara umum jasa transportasi berfungsi mengangkut penumpang dari tempat yang satu ketempat yang lain. Inilah manfaat utama dari suatu produk jasa transportasi. 
Perbedaan dalam nilai berpengaruh terhadap harga, artinya semakin tinggi nilai yang melekat pada produk, semakin tinggi pula harga yang harus dibayar oleh konsumen. Sebaliknya semakin rendah nilai yang diperoleh semakin rendah pula harga yang harus dibayar oleh konsumen (Yusuf Qardhawi, 1997: 199).

Harga bagi konsumen merupakan pengorbanan yang telah dikeluarkan guna memperoleh produk barang atau jasa. Bagi konsumen pengorbanan bukan sematamata harga, akan tetapi masih mengandung sejumlah unsur lainnya seperti pengorbanan waktu, pengorbanan biaya, pengorbanan energi dan pengorbanan perasaan yang digunakan untuk mendapatkan informasi tentang produk barang dan atau produk jasa yang diberikan sampai dengan keputusan pembelian. Biaya jasa transportasi Go-Jek masih terjangkau oleh masyarakat Kota Padang. Seperti pengguna jasa Go-Ride dan Go-Car sesaui dengan jarak tempuh perjalan.

Berdasarkan hasil wawancara penulis kepada pengguna jasa transportasi Go-Jek yang mengunakan aplikasi Go-Car. Fela mengatakan jasa tranportasi GoCar digunakan pada hari hujan untuk pergi ke kampus. Sebelum ada jasa transportasi Go-Jek, Fela mengunakan jasa transportasi umum Trans Padang. setelah itu mengunakan jasa ojek pangkalan ke fakultas.

Mimi suryani mengatakan mengunakan jasa tranportasi Go-Car setiap hari bersama teman kost untuk pergi ke kampus. Kemudian pada hari minggu mengunakan jasa Go-Car untuk jalan-jalan. Sebelum ada jasa transportasi Go-Jek, mimi suryani mengunakan angkot ke kampus dan jarang hari libur pergi berjalanan. Tetapi setelah jasa transportasi Go-Car, mimi suryani sering berjalanan bersama temannya.

Setiap orang mukmin berusaha mencari kenikmatan dengan cara memenuhi perintah-Nya dan memuaskan dirinya sendiri dengan barang-barang dan anugerah yang di ciptakan Allah untuk umat manusia demi kemaslahatan. Konsumsi berlebih-lebihan, yang merupakan ciri khas masyarakat yang tidak mengenal Tuhan, dan disebut dengan israf (pemborosan) atau tabzir menghambur-hamburkan harta tanpa guna.

Tabzir berarti menggunakan harta dengan cara yang salah, yakni menuju tujuan yang terlarang, hal-hal yang melanggar hukum atau dengan cara yang tanpa 
aturan. Ajaran Islam menganjurkan pola konsumsi dan penggunaan harta secara wajar dan berimbang, yakni pola yang terletak di antara kekikiran dan pemborosan.Allah akan sangat mengecam setiap perbuatan yang melampaui batas. Qs al-A'raaf (7):31:

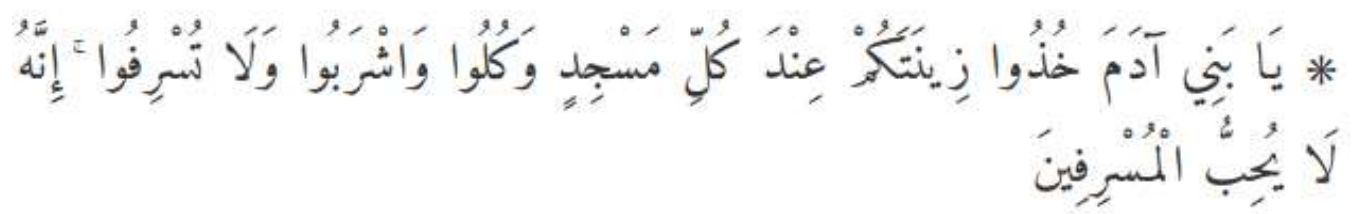

Artinya: Hai anak Adam, pakailah pakaianmu yang indah di setiap (memasuki) mesjid, makan dan minumlah, dan janganlah berlebih-lebihan. Sesungguhnya Allah tidak menyukai orang-orang yang berlebih-lebihan. QS al-Maidaah (5):87

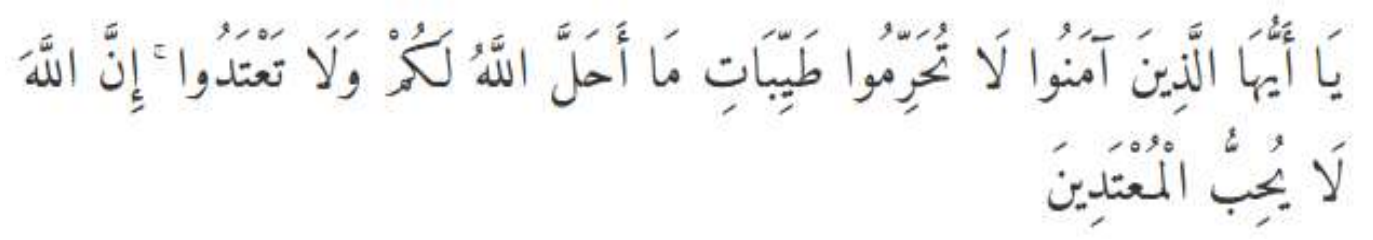

Artinya: Hai orang-orang yang beriman, janganlah kamu haramkan apa-apa yang baik yang Telah Allah halalkan bagi kamu, dan janganlah kamu melampaui batas. Sesungguhnya Allah tidak menyukai orang-orang yang melampaui batas.

Sebagaimana yang telah diatur tentang larangan mempunyai sikap israf. Pada jasa transportasi Go-jek menyediakan jasa penggantaran. Sistem yang transparan dalam perhitungan biaya yang akan dikeluarkan. Dengan begitu dapat dilakukan perhitungan biaya pengeluaran. Kepada pengguna jasa transportasi yang mempuyai sikap israf akan senantiasa melakukan perjalanan. Seperti sering berliburan dengan mengunakan jasa transportasi Go-Jek pada aplikasi Go-Ride dan Go-Car.

Dimana pada aplikasi Go-Jek juga menampilkan informasi mengenai nominal biaya yang harus dibayar oleh konsumen. Total harga yang ditampilkan di aplikasi sebelum menggunakan jasa Go-Jek memberikan kepastian pengguna mengenai biaya. Dapat memprediksi dan menyediakan uang yang harus dikeluarkan dalam sehari apabila mengunkan jasa transportasi Go-Jek.

Perhitungan harga didasarkan pada jarak yang ditempuh oleh konsumen yaitu dihitung per kilometer. Kilometer pun dihitung secara tepat berdasar GPS. Pengguna dapat mempertimbangkan uang yang harus dikeluarkan berdasarkan 
nominal yang tertera dalam aplikasi. Konsumen tidak harus membayar biaya jasa transportasi secara tidak jelas tanpa adanya ketentuan tarif standar.

Pembayaran mempunyai dua pilihan yaitu secara tunai dan Go-Pay. Go-Pay memberikan kemudahan kepada pengguna jasa transportasi Go-Jek dalam pembayaran. Dengan mengunakan saldo yang telah di isi sebelumnya yang akan dipergunakan dalam pembayaran perjalanan. Sehingga pembayaran mengunakan Go-Pay memberikan kepastian.

Pada wawancara yang dilakukan kepada Reni mengatakan bahwa dia mengunakan jasa transportasi Go-Jek, untuk mengatarkan ketempat kerja bimbel dengan mengunakan Go-Ride kemudian pada hari minggu dia beserta teman kerja menggunakan Go-Car untuk jalan-jalan di sekitar Padang. Mereka membagi biaya jasa transportasi dengan mengunakan Go-Car. Berdasarkan penjelasan mengenai sikap israf di atas berdasarkan hasil wawancara penulis, mereka melakukan sikap israf menggunakan jasa transportasi Go-Jek Go-Car.

\section{Waktu}

Aplikasi Go-Jek menyediakan peta yang tersambung dengan sitem GPS (Global Positioning Systems) sistem ini dapat dipergunakan untuk melakukan kontrol terhadap lokasi keberadaan pengemudi Go-Jek. Mengetahui jarak tempuh yang akan dilalui oleh pengemudi hingga sampai pada lokasi penjemputan. Dan juga pada lokasi pengantaran pengguna jasa transportasi Go-Jek. Sehingga arah yang dituju sesuai dengan yang di pesan.

Berdasarkan wawanacara penulis kepada Nur Hayati yang mempunyai sebuah toko foto copy. Mengatakan dengan adanya transportasi jasa Go-Jek membantu dalam mengunakan waktu, saya mengunakan jasa Go-Ride untuk membeli bahan kertas yang habis. Tanpa menutup toko saya dapat memperoleh kertas yang dibutuhkan untuk melanjutkan pekerjaan.

Endi Irawan mengatakan setelah ada jasa transportasi Go-Jek untuk pergi dan pulang kerja mengunakan jasa transportasi Go-Ride, tepat waktu penjemputan ke lokasi oleh pengemudi. Menghemat waktu dan tenaga, sehingga tidak harus ke pinggir jalan raya menunggu angkot untuk pergi kerja. Berdiri sambil menunggu jemputan di depan rumah saja. 


\section{Kenyamanan}

Kenyamanan menunjukkan keinginan yang memberikan rasa nyaman dan kemudahan kepada manusia dan yang gunanya secara umum lebih besar daripada biayanya. Nyaman berada di atas penting bagi kehidupan dan pemenuhannya menjadikan hidup lebih mudah dan menyenangkan. Kenyamanan saat menggunkan jasa transportasi Go-Jek baik itu Go-Ride dan Go-Car. Di mana fasilitas yang diberikan membuat nyaman, seperti jika menggunakan Go-Ride di sediakan helm sedangkan Go-Car ber-AC serta penggunaan sabuk pengaman.

Kepada pengemudi telah memenuhi persyaratan sehingga kenyamanan untuk naik Go-Jek tidak diragukan karena sepeda motor yang digunakan oleh pengemudi Go-Jek memiliki standarlisasi yang sudah diterapkan oleh Go-Jek. Misalnya memiliki dua kaca spion dan kondisi motor yang cukup baik. Juga merasa terlindungi dengan layanan transportasi Go-Jek yang menyediakan helm. Kecepatan yang dilakukan oleh pengemudi tidak melampaui batas kecepatan maksimum. Mengutamakan keselamatan merupakan prioritas utama pengemudi.

Berdasarkan wawancara penulis, Ratna Sari mengatakan kenyamanan mengunakan jasa transportasi Go-Ride yang dilengkapi dengan jeket dan helm membuat dalam perjalanan menjadi nyaman.Mutiara Rizqa Chairunnisa mengatakan fasilitas yang ada pada jasa transportasi Go-Jek seseuai dengan standarlisasi pada kendaraan umum lainnya. Menggunaka aplikasi jasa Go-Car yang kenyamaan yang diberikan pengemudi fasilitas mobil yang dilengkapi dengan sabuk pengaman dan AC membuat lebih nyaman.

\section{Keamanan}

Tujuan Ekonomi Islam adalah menciptakan manusia yang aman dan sejahtera. Al-Quran dan hadits menyebutkan sejumlah kehidupan yang baik dan dengan sengaja Allah menciptakannya untuk hamba-Nya. Salah satu tanda yang jelas tentang kenikmatan yaitu nikmat kendaraan, baik itu hewan ataupun mobil. Terdapat dalam surah an-Nahl (16) : 8.

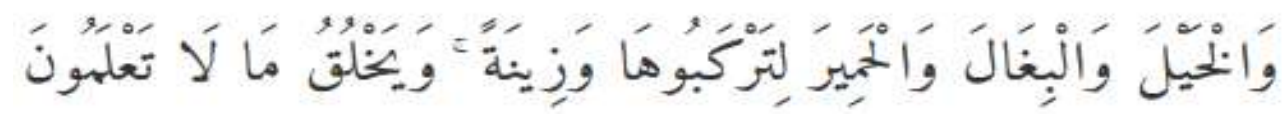


Artinya: Dan (Dia Telah menciptakan) kuda, bagal dan keledai, agar kamu menungganginya dan (menjadikannya) perhiasan. dan Allah menciptakan apa yang kamu tidak mengetahuinya.

Nabi juga menyebutkan bahwa di antara unsur kebahagian ialah kendaraan yang nyaman. Para fuqaha menyebutkan bahwa kuda termasuk kebutuhan asasi manusia. Jika dianalogikan, maka kuda pada zaman Nabi sama dengan mobil pada saat ini. Mobil, sarana yang mendekatkan jarak yang jauh itu sangat dibutuhkan dalam kehidupan seseorang sehingga ia sangat mengharapkannya. Mereka yang kurang mampu ingin memiliki sepeda motor. Kalau ia juga belum mampu memilikinya, negara dianjurkan untuk menyediakan angkutan umum (Yusuf Qardhawi, 1997: 61).

Pada aplikasi Go-Jek menampilkan informasi mengenai identitas pengendara Go-Jek, seperti foto, nama dan nomor telepon. Identitas ini ditampilkan agar konsumen Go-Jek dapat mengetahui yang melayani pesanannya. Bahwa nomor telepon pengemudi yang disediakan berguna apabila pengguna ingin menghubungi pengemudi Go-Jek melalui telepon.

Transparansi data diri pengemudi Go-Jek juga memberikan rasa aman karena memberi jaminan ke pengguna jasa Go-Jek. Ketika pengguna jasa Go-Jek tidak merasa aman oleh sikap pengemudi saat dalam perjalanan. Pengguna bisa melaporkan kepada pihak kantor Go-Jek melalui sms layanan yang disediakan setelah selesai perjalanan. Pesan pengguna Go-Jek akan di proses oleh pihak kantor Go-Jek, memberikan teguran dalam bentuk sangsi sesuai dengan perbuatan yang dilakukan oleh pengemudi.

Sesuai dengan wawancara penulis kepada pengguna jasa transportasi GoJek, Sitri Ayani mengatakan jasa transportasi pada aplikasi Go-Ride yang digunakannya untuk berpergian selama ini aman dengan sistem operasional jasa transportasi Go-Jek yang bersifat transparan. Dan juga ummu kalsum mengatakan keaman juga dirasakan saat mengunakan jasa transportasi Go-Car untuk mengatarkan ke kampus dengan data pengemudi yang lengkap sehingga menghilangkan rasa kekhawatiran untuk menggunakan jasa transportasi Go-Jek. 
Kemudian wawancara penulis kepada pimpinan kantor Go-Jek di Kota Padang mengatakan bahwa belum ada masalah dalam bentuk perbuatan asusila yang di timbulkan oleh pengemudi kepada pengguna aplikasi jasa Go-Jek baik itu Go-Ride dan Go-Car. Seperti halnya pengguna Go-Jek telah mengetahui siapa yang akan menjemput ke lokasi yang dipesan. Dapat dilihat sebagai berikut nama, foto, nomor telepon serta tarif yang akan dibayar oleh pengguna jasa transportasi GoJek.

Data pribadi pengemudi yang ada dilayanan transportasi Go-Jek memberikan rasa aman untuk naik Go-Jek karena telah diketahui siapa yang akan menjemput di lokasi. Profil yang ada pada layanan jasa transportasi Go-Jek begitu jelas sehingga dengan adanya layanan ini memberikan keamanan bagi pengguna jasa transportasi Go-Jek.

Dalam perspektif Islam, kebutuhan ditentukan oleh mashlahah. Pembahasan konsep kebutuhan dalam Islam tidak dapat dipisahkan dari kajian perilaku konsumen dalam kerangka Maqasid Syariah. Di mana tujuan Syariah harus dapat menentukan tujuan perilaku konsumen dalam Islam. Seperti, pengguna jasa transportasi Go-Jek pada aplikasi Go-Ride dan Go-Car. Jasa transportasi merupakan kebutuhan masyarakat pada zaman sekarang.

Pada jasa transportasi Go-Jek telah diterapkan kenyaman dengan menfasilitasi kendaraan yang akan digunakan untuk mengantarkan pengguna jasa transportasi Go-Jek. Kenyamanan yang diberikan akan memberikan kepuasan oleh pengguna sehingga berulang mengunakan jasa transportasi Go-Jek.

Dengan demikian semua barang atau jasa yang dimiliki kekuatan untuk memenuhi lima bagian pokok termasuk dalam kategori dlaruriyah. Berbagai macam barang atau jasa tersebut dapat dikatakan memiliki mashlahah bagi umat manusia. Kehadiran jasa transportasi Go-Jek yaitu Go-Ride dan Go-Car memberikan mashlahah kepada masyarakat di kota Padang. Sistem jasa transportasi Go-Jek memberikan kemudahan, tarif biaya yang terjangkau, waktu yang cepat dan tepat, kenyamanan fasilitas, serta keaman informasi pribadi pengguna. 


\section{KESIMPULAN}

Berdasarkan uraian pada beberapa pembahasan sebelumnya pada penelitian terhadap keputusan konsumen memilih jasa transportasi Go-Jek di Kota Padang maka penulis dapat menyimpulkan kehadiran jasa transportasi Go-Jek yaitu pada aplikasi Go-Ride dan Go-Car memberikan kepuasan (mashlahah) terdiri dari manfaat dan berkah dalam memenuhi kebutuhan manusia yang bertujuan memudahkan kehidupan dan menghilangkan kesempitan (hajjiyah) dan menghendaki kehidupan yang indah dan nyaman (tahsiniyah) di kota Padang. Dalam perspektif Islam, kebutuhan ditentukan oleh mashlahah. Konsep kebutuhan dalam Islam tidak dapat dipisahkan dari perilaku konsumen dalam kerangka Maqasid Syariah. Di mana tujuan Syariah harus dapat menentukan tujuan perilaku kosumen dalam Islam. Pada sistem jasa transportasi Go-Jek memberikan kemudahan, tarif biaya yang terjangkau, waktu yang cepat dan tepat, kenyamanan fasilitas, serta keaman informasi pribadi pengguna.

Pada penelitian terdahulu implikasi hal waktu, kemudahan, biaya, dan keamanan. Pengumpulan data menggunakan metode kualitatif terhadap penelitian yang dilakukan penulis jasa transportasi Go-Jek di Kota Padang adalah metode yang digunakan peneliti terdahulu. Dimana pada aplikasi Go-Jek terutama aplikasi Go-Ride dan Go-Car.

\section{DAFTAR PUSTAKA}

Faizal Noor Henry, Ekonomi Media. Jakarta: Rajawali Pers, 2010 , Ekonomi Manajerial. Jakarta: Raja Grafindo Persada, 2007

Gunawan Herry, Pengantar Transportasi dan Logistik. Jakarta: Raja Wali Pers, 2015

Ika Yunia Fauzia dan Abdul Kadir Riyadi, Prinsip Ekonomi Islam Perspektif Maqasid Al-Syariah. Jakarta: Kencana, 2014

J.Setiadi Nugroho, Perilaku Konsumen: Perspektif Kontemporer pada Motif, Tujuan, dan Keinginan Konsumen. Jakarta: Kencana, 2003

Jusmaliani, Bisnis Berbasis Syariah. Jakarta: Bumi Aksara, 2008

KartonoKartini, PengantarMetode Riset Social, Bandung: Bandar Maju, 1990.

Kother Philip, ManajemenPemasaran, Jakarta:Erlangga, 2006.

M.Nur Rianto Al Arif dan Euis Amalia, Teori Mikroekonomi Suatu Perbandingan Ekonomi Islam dan Ekonomi Konvensional, Jakarta: Kencana, 2010.

Muhajir Noeng, Metode Penelitian Kualitatif, Jakarta: Rake Serasin, 1998. 
Nazir Moh, Metode Penelitian, Bogor: Ghalia Indonesia, 2005. , Metode Penelitian, Ciawi :Ghalia Indonesia, 2005.

Niti Susastro Mulyad, Perilaku Konsumen dalam Perspektif Kewirausahaan. Bandung: Alfabeta, 2012

Nuruddin Iqbal Amiur, Ekonomi Syariah Menepis Badai Krisis dalam Semangat Kerakyatan, Bandung: Perdana Mulya Sarana, 2009.

Oni Sahroni dan Adiwarman A.Karim, Maqasdid Bisnis \& Keunangan Islam Sistesis Fikih dan Ekonomi. Jakarta: Raja Grafindo, 2016

Pemerintah Kota Padang Badan Perencanaan Pembangunan Daerah (BAPPEDA), Profil Daerah Kota Padang Tahun 2017.

Pengaruh Kualitas Pelayanan Transfirtasi Oline Gojek terhadap Kepuasan pada Pelanggan Mahasiswa Adminitrasi Niaga Politeknik Negeri Jakarta, Jurnal Epigram, Vol 13 No. 2 Oktober 2016.

Philip Kotler dan Gary Amstrong, Prinsip-Prinsip Pemasaran, Jakarta: Erlangga, 2001

Pimpinan Kantor Cabang Go-Jek Di Kota Padang, Wawancara Langsung, Tanggal 25 Januari 2018 Pukul 13.30 WIB

Pusat Pengkajian dan Pengembangan Ekonomi Islam (P3EI), Ekonomi Islam, Jakarta: Rajagrafindo Persada, 2014.

Qardhawi Yusuf, Norma dan Etika Ekonomi Islam, Jakarta: Gema Insani Press, 1997.

Rozalinda, Ekonomi Islam Teori dan Aplikasinya pada Aktivitas Ekonomi. Jakarta: Rajagrafindo Persada, 2014

Salim Abbas, Manajemen Transportasi. Jakarta: Raja Wali Pers, 2008

Salim Abbas, Manajemen Transportasi. Jakarta: Rajawali Pers, 2015

Save Dagun M, Kamus Besar Ilmu Pengetahuan, Jakarta: Lembaga Pengkajian Kebudayaan Nusantara, 2006.

Sigit Winarto \& Sujana Ismaya, Kamus Besar Ekonomi, Bandung: Pustaka Grafika, 2010.

Sudarsono Heri, Bank dan Lembaga KeuanganSyariah, Yogyakarta: Ekonisa, 2003.

Konsep Ekonomi Islam Suatu Pengatar, Yogyakarta: Ekonisia, 2004. Konsep Ekonomi Islam, Yogyakarta: Adipura, 2003.

Sugiyono, Memahami Penelitian Kualitatif, Bandung: Alfabeta, 2009.

Metode Penelitian Kuantitatif, Kualitatif, dan $R$ \& D, Bandung: Alfabeta, 2006.

Sumarwan Ujang, Perilaku Konsumen Teori dan Terapannya dalam Pemasaran. Bogor Selatan: Ghalia Indonesia, 2002

Tim Penyusun Kamus Pusat Bahasa, Kamus Bahasa Indonesia, Jakarta: Pusat Bahasa, 2008. 